Several developments have helped to interrupt the smooth attainment of the timetable spelled out a year ago by the council of Cern. For one thing, there has been the devaluation of sterling, which explains why the United Kingdom and Spain were not able, at the council meeting last week, even to approve the budgets for 1968-197.5 million Swiss francs for the basic costs of the Meyrin laboratory and 28.43 million Swiss francs for the programme connected with the Intersecting Storage Rings. The British Government is particularly concerned with the international consequences of devaluation, for something like $£ 5$ million a year out of the annual budget of $£ 33$ million of the Science Research Council is at present allocated to overseas expenditure. The question which has to be settled before it is possible for the Science Research Council to participate even in the ordinary activities of Cern is whether such a large and uncovenanted increase of real expenditure is possible without harming the rest of the council's work.

The $300 \mathrm{GeV}$ project seems also to have been held up by doubts in West Germany about the desirability of the particular design worked out by the European Committee for Future Accelerators and published in July. Especially since details of the design of the United States $200 \mathrm{GeV}$ accelerator at Weston, Illinois, have been made known in the past few months, there have been some suggestions that Europe might hope to obtain better value for money by building a somewhat simpler machine. The meeting of the Cern council last week seems to have reaffirmed the earlier view that a European machine should be generously provided with experimental facilities of all kinds, but at the same time it seems to have been acknowledged that the studies of the $300 \mathrm{GeV}$ problem will be continued at Cern, so that the design already published must be regarded more as a feasibility study than as the detailed prospectus which it seemed to be a few months ago. To this end, the council last week did approve an allocation of $\$ 4$ million for the continuing programme of planning and design. Although it is theoretically possible that a final decision on the accelerator could be taken at any one of the four council meetings due to be held in the year ahead, the optimists who hope that everything will be settled by June are likely to be disappointed.

\section{More about Stansted}

LoNDoN's third airport was discussed at Westminster again last week, this time in the Lords. Lord Macpherson of Drumochter initiated the debate, the first in the House of Lords on the subject since the White Paper was published in May with the decision to build at Stansted. In the eight hour debate only five of the thirty-one speakers supported the government's decision. The feeling among the rest was not that Stansted was necessarily the wrong site for the airport, but that public opinion had not been satisfied that the choice was the best. The facts behind the present situation were put forward-the Interdepartmental Committee report of 1963 , calling for an inquiry; the inquiry inspector calling for a further review of the problem; the government review held in private coming out in favour of Stansted. Doubt about the decision to build arose because the final review was held in private, particularly as the reasons for this privacy were inconsistent. The White Paper stated that the urgency of the problem precluded a public inquiry, which anyway would produce no additional facts. In the debate, however, Lord Kennet said, for the government, that the proper discussion of defence issues could not be carried out in public. Viscount Dilhorne submitted that because a consider. able number of new facts had come to light since the original inquiry, it should be re-opened in public, in the manner recommended by the Franks Committee. Only in this way would "broad justice to those affected" be done and be seen to be done.

The White Paper suggested that a second pair of runways would be added to the two originally planned for Stansted. This proposal was not considered at the original inquiry, and would significantly alter effects on the area. Silverstone received a passing mention as an alternative, but most attention was focused on Foulness. Included in the cost of an airport at Foulness was $£ 25$ million (a much questioned figure) for moving the Shoeburyness firing range. Lord Beswick, putting the government's case, admitted he had "never treated this one very seriously". His main objection to the building of an airport on land reclaimed from the sea was based on the length of time it would take, quite apart from the time involved in holding a public inquiry. Lord Beswick believed the loss of food production from building an airport on good Stansted land, estimated at $£ 1$ million a year by Lord Butler, would be far outweighed by the foreign currency gained from a third airport built in the early seventies. If there was no such airport by 1977 , on British Airports Authority estimates, nearly 3 million overseas visitors would have to be turned away, losing Britain an estimated $\mathfrak{E 3 6}$ million in foreign currency from landing fees, spending money and airline earnings.

Lord Plowden described the White Paper as "full of statements presented as facts which the public are expected to accept". He remarked on the paucity of information on cost-benefit analysis. The social costs involved might be so heavy that the country could well afford the time to investigate the situation again. The theory that Whitehall is always right was questioned by Lord Balfour, who quoted as an example the speech he himself made as Minister of Aviation in 1939 , which was full of miscalculation about airports.

The belief of the Lords was that there is still time to reconsider the Stansted decision. The most important product of the whole debate was the announcement by Lord Kennet that the government is intending to improve the planning laws for projects on the scale of airports. Under the present system planning permission is sought for one specific site only, but the proposed Town and Country Planning Bill would allow alternative sites to be listed in the request for planning permission. An inquiry would then determine which of the alternatives was most suitable before the present procedure is gone through.

\section{Changing Units}

A commitTeE appointed by the Ministry of Technology to investigate the adoption of metric units has reported that, unless steps are taken now, an important sector of the economy may be slow to accept the new units. The committee, formed by the CBI at the request of the Standing Joint Committee on Metrication, a 
Ministry of Technology body, has investigated preparations being made in the non-industrial sector of the economy, which includes bottling and packaging, the retail trade and transport. Because this sector is not the direct responsibility of any government department, the CBI has concluded that the change to SI units is not being properly organized. The CBI is alarmed that the advantages to industry of the change to the new units will be wasted because the packaging industry, and the retail outlets, will still be using Imperial units.

In fact the change to SI units is happening more rapidly than most people suspect. As well as the encouragement given to the scientific journals by the Royal Society (Nature, last week), the Department of Education and Science and the Confederation of British Industry are well aware of the implications of the change. Abroad, the change is going even faster-by 1975, SI enthusiasts say, only the United States and Canada will be using Imperial units, and thcy can be expected to change rapidly as soon as they begin to feel isolated. In Britain, the timetable for the change was set out in a parliamentary answer by Mr Douglas Jay when he was President of the Board of Trade. He said that by 1975 the majority of British industry should have moved over to SI units. Unfortunately, he said nothing about the non-industrial sector of the economy, and no government departmont has taken it under its wing. For this reason, the CBI has been driven to suggest the establishment of a Metrication Board, rather similar in structure to the Decimal Currency Board. The board would have as its responsibility the co-ordination of metrication in the various parts of the economy which have so far been lagging. For one thing, the SI system proposes a standardized set of package sizes, but the packaging industry is not yet planning effectively for the change. For another, all the road signs in the British Isles will need to be changed from miles per hour into kilometres per hour. Some observers, alarmed at the slow progress, are inclined to point out that when Sweden changed from the left to the right side of the road it was after four ycars of the most intensive planning. Similar planning, they suggest, will be needed for the successful adoption of the metric system.

The proposed Metrication Board, the CBI says, should not be a part-time body. What is needed is a body represcnting both government departments and the interests concerned, with a full-time chairman and secretariat. And, if the progress towards metrication is not to be slowed down, the board should be set up as a matter of urgency.

\section{Instruments for Technology}

THe Scientific Instrument Research Association (SIRA) spends the $\$ 0.5$ million it receives each year from its members and from the Ministry of Technology on trying to promote measurement and control technology in science and industry. But the association suffers because most of the industrial companies working with anything like advanced technology are able to look after thcir own measurement and control systems. The SIRA laboratories are on the whole left with the small fry-the craft industries. For them SIRA does a good job. It has, for example, taught British biscuit manufacturers how to measure the water content of biscuits by measuring colour. It has also devised ways of testing coin blanks before minting and has used a laser for micro-machining.

Given the dominance of the German and Japanese optical industries, it is perhaps surprising that one of the outstanding achievements of SIRA has been the development of two very sophisticated machines for testing lens performance. This work began 9 years ago with a contract from the then Ministry of Aviation, but now receives international sponsorship. One of the machines, now commercially available and slowly finding a world market, measurcs the optical transform function of a lens so that the quality of the image can be specified objectively. The other, a pupil scanning lens tester, measures the extent to which the wave front emerging from a lens deviates from being spherical. A computer attachment can then calculate the various aberrations present in the lons.

SIRA hopes that this work will eventually lead to a much needed international agreement to specify lens performance objectively, in terms of optical transform functions.

\section{No Buns for the Elephants}

THe decision of the council of the Zoological Society to ban all feeding by visitors at London Zoo and Whipsnade Park from the beginning of 1968 is the final stage of the policy adopted in 1965 in the interests of the health and general wolfare of the animals. The policy of no feeding has been introduccd gradually as new animal houses have been opened, and now the ban is to apply to the romaining animals, the most important of which are the monkeys and apes, some of the bears, the elephants at London and the herd animals at Whipsnade.

Visitors to the zoos will find with their guide books and pamphlets a leaflet telling them not to feed the animals and explaining why the ban is considered necessary. The two zoos have veterinary and supplies officers who know the nutritive requirements of the animals and who try to provide them with a balanced diet. When the visitors fecd the animals, unbalanced diets are unavoidable, and these are not good for the animals, who may do themselves harm, sometimes serious, by over-eating or eating proffered food which is quite unsuitable for them. There may also be accidents, not always as serious as the death of Dicksie the elephant this year, when she fell into the ditch around the enclosure while stretching out for food.

The visitors too will be safer when the ban is enforced; during one year at London 180 people have been bitten by monkeys, parrots, cockatoos, ponies and other animals. During the same year elephants at London seized fourteen coats, twelve handbags, ten cameras, eight gloves and six return tickets to Leicester, damaging them all beyond repair.

The council of the Zoological Society also says that the control of feeding in zoos is necessary to create conditions in which the animals may breed and rare species may be conserved. Some animals are now so rare that they are only available from surpluses bred in other zoos. These include the orang-utan, the Europcan bison and Père David's decr. The last two are now extinct in the wild, and the Zoo is determined that unbalanced feeding should not be allowed to make them extinct in zoos as well. 